\title{
Evolution of the Maturation Point of Wine Grapes Intended for Juice Processing
}

\author{
Angelica Bender ${ }^{1}$, Vagner Brasil Costa ${ }^{2}$, Marcelo Barbosa Malgarim ${ }^{1}$, Valmor Guadagnin ${ }^{3}$, Vinícius Caliari ${ }^{4}$ and \\ Suélen Braga de Andrade ${ }^{1}$ \\ 1. Federal University of Pelotas (UFPel), Capão do Leão University Campus, Capão do Leão, RS, CEP 96900-010, Brazil \\ 2. Federal University of Pampa (UNIPAMPA), Dom Pedrito, CEP 96450000, RS, Brazil \\ 3. Instituto Federal Sul-rio-grandense (IFSul), Education Science and Technology, Campus Pelotas Visconde da Graça, Av. \\ Engenheiro Ildefonso Simões Lopes, 21-Três Vendas, Pelotas, RS, CEP 96060-290, Brazil \\ 4. University of Western Santa Catarina (UNOESC), Brazilian Agricultural Research Company-Epagri, R. Paese, 198-Bairro \\ Universitário, Videira, SC, CEP 89560-000, Brazil
}

\begin{abstract}
Rainy years especially in the ripening period end up weakening grape quality, thus making it unsatisfactory for winemaking. The possibility of using wine grape varieties in the preparation of juices presents an alternative to the grapes that do not reach ideal harvest for winemaking. Assuming that the preparation of juice from wine grapes can be an alternative to these grapes which in harvests are considered poor for winemaking and can be harvested in advance, thus preventing losses from late cycle disease and excessive spending on phytosanitary treatments, the present study aimed to evaluate the juices made from "Cabernet Sauvignon", "Merlot" and "Chardonnay" grapes harvested at different points of maturation, and subsequently compare with current legislation. Physicochemical analysis of titratable acidity (TA), soluble solids (SS), relative density, total sugar, alcohol, volatile acidity and SS/TA ratio was carried out on the juices produced at three sampling points $\left(15,17\right.$ and $19{ }^{\circ}$ Brix). The results showed variability between treatment factors (cultivars and points of maturation). Analyses of titratable acidity, soluble solids, SS/TA ratio, relative density, total sugars and volatile acidity showed significance for the interaction between the tested treatment factors. For the variable alcohol, there was no significance for the effect of variety, maturation stage or the interaction between the factors of treatment. It was concluded that Cabernet Sauvignon juice met the parameters set by law at $17^{\circ}$ Brix, while Chardonnay and Merlot juices showed consistent results only at harvest point $19^{\circ}$ Brix.
\end{abstract}

Key words: Vitis vinifera, maturation point, grape juice, physicochemical quality.

\section{Introduction}

Grapes stand out as one of the most consumed fruits in the world, not only in the consumption of the fruit in natura, but as processed production as well. Among the products derived from this crop, grape juice is considered to be one of the main ones and has been presenting perspectives of increase in the market [1]. Grape juice may be prepared with any variety that reaches suitable maturation and is in a good state of health. In general, the more mature grapes favor the better juice quality, because besides having higher

Corresponding author: Angelica Bender, M.Sc., research field: temperate climate fruit culture. sugar content, they have lower acidity, and consequently, higher sugar/acidity ratio [2].

Grape is a non-climacteric fruit, therefore, it is of fundamental importance that the harvest takes place at the maximum moment of expression of its quality potential in a particular crop or region. The ideal maturation for harvesting is evidenced by the appearance, consistency and mainly the sugar content in the must. Thus, it is necessary to monitor the maturation by means of sensorial and chemical analyses every two or three days of representative samples of the vineyard [2, 3].

The ideal is to harvest the grapes by the degree of maturation and not due to phytosanitary problems 
caused especially by bunch rot [4]. Rainy years, especially in the maturation period, end up weakening the quality of the grape, thus making it unsatisfactory for winemaking. The possibility of the use of grape varieties in the elaboration of juices presents itself as an alternative for harvests, in which the grapes do not reach ideal point of harvest for the elaboration of wines.

Based on the premise that the production of juices from grapes can be an alternative for the use of crops which are considered bad for vinification and can be harvested in advance, thus avoiding losses with end-of cycle diseases and excessive expenditures with phytosanitary treatments, the present study mainly aimed to evaluate the juices elaborated from the grape varieties Cabernet Sauvignon, Merlot and Chardonnay harvested at different maturation points.

\section{Materials and Methods}

\subsection{Experiment Area}

The grapes used as raw material for the elaboration of the juices were the European varieties (Vitis vinifera): Cabernet Sauvignon, Merlot and Chardonnay from the 2015 crops grown in a commercial orchard located in the municipality of São Lourenço do Sul (31⒉ $1^{\prime} 54^{\prime \prime} \mathrm{S}, 51^{\circ} 58^{\prime} 40^{\prime \prime} \mathrm{W}, 26 \mathrm{~m}$ altitude). The climate of the region is of the type subtropical, temperate with hot and humid summers and quite cold winters [5]. The soil is classified as Bruno-grayish argisols, red-yellow argisols and litolics and Regolithic neosols, and composed of plateaus and plains [6]. The municipality of São Lourenço has no meteorological station, thus data from the municipality of Pelotas were used since it belongs to the same micro-region of this municipality. The data on the minimum and maximum temperature and rainfall of the municipality of Pelotas, related to the duration of the experiments were obtained from the meteorology laboratory of Embrapa Clima Temperado [7]. The mean minimum temperature was $20.2{ }^{\circ} \mathrm{C}$, the mean maximum temperature was $27.4{ }^{\circ} \mathrm{C}$ and the total precipitation was $168.8 \mathrm{~mm}$ for the month of January, 2015. For February, 2015, the average minimum temperature was $20.8^{\circ} \mathrm{C}$, the mean maximum was $25.6{ }^{\circ} \mathrm{C}$ and the total precipitation was $407.4 \mathrm{~mm}$.

\subsection{Identification of Plants}

Ninety plants were selected from each cultivar, arranged in three distinct rows for the experiment. The plants were harvested under a Paulsen 1103 grating system and pruned in spore cord. The space between plants was $2 \mathrm{~m}$, and the space between rows was $3 \mathrm{~m}$. The management and cultural treatment were carried out following the technical recommendations of the culture. The harvest was conducted manually, differing the dates between the varieties and harvesting points, during the months of January and February 2015 (Fig. 1). About $20 \mathrm{~kg}$ were set aside to elaborate the juice of each cultivar in each point of harvest. The collection points were previously determined according to the soluble solids content, being 15,17 and $19^{\circ}$ Brix for all cultivars.

\subsection{Phenological Monitoring}

Monitoring of the phenological behavior of the grapevine production cycle during the pruning period was carried out by means of visual observations by visits to the vineyard, carried out every $5 \mathrm{~d}$ until the beginning of maturation, and subsequently intensified visits to $3 \mathrm{~d}$ intervals.

Phenological characterization was performed in 20 randomly selected plants, which were used for the phenological scale evaluations [8]. The durations of the different stages observed are shown in Fig. 2.

\subsection{Juice Production}

The juices were elaborated in the Postharvest Laboratory of the Federal University of Pelotas (Pelotas, RS/Brazil). The extraction of the must occurred via a steam extractor with capacity for $20 \mathrm{~kg}$ of the fruit. Initially, the berries were destalked and 


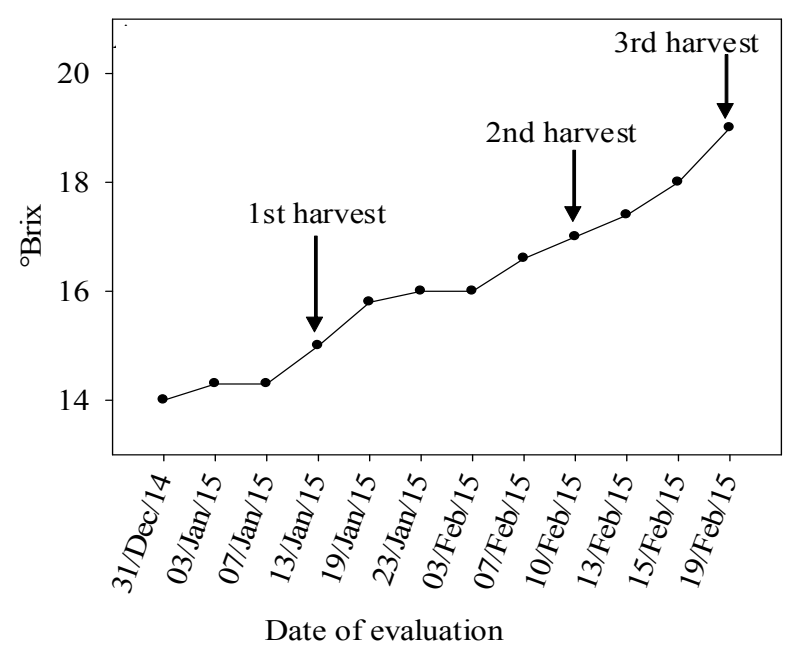

(a)

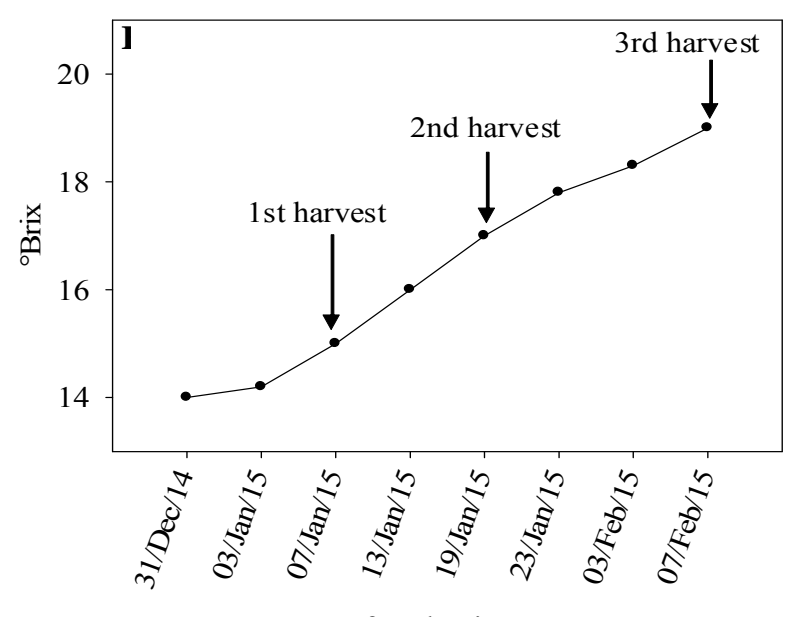

Date of evaluation

(b)

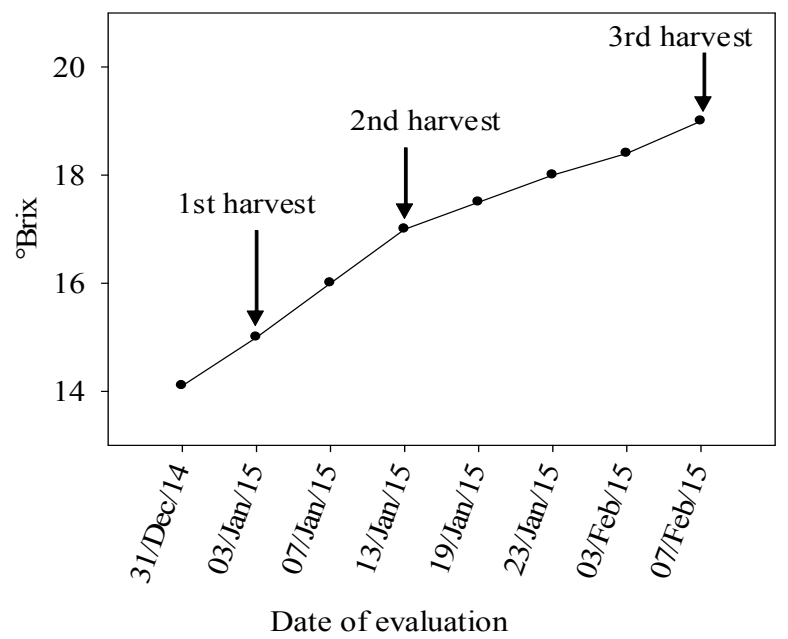

(c)

Fig. 1 Harvest points of Cabernet Sauvignon (a), Merlot (b) and Chardonnay (c) for the preparation of juices.

1st harvest: $15{ }^{\circ}$ Brix; 2nd harvest: $17{ }^{\circ}$ Brix; 3rd harvest: $19^{\circ}$ Brix. selected manually, excluding the damaged ones and incomplete maturation. Afterwards, they were placed in the perforated container, fitted in the external container, and both coupled on the water tank that was accommodated on a gas cooker, for the generation of heat. After approximately $20 \mathrm{~min}$, the must began to flow through the outlet tube, being put back on the grapes until the temperature of $85^{\circ} \mathrm{C}$ was reached.

Bottling of the samples lasted for about $1 \mathrm{~h}$ and 30 min, controlling the temperature inside the bottle with the aid of a thermometer (Incoterm, $-10{ }^{\circ} \mathrm{C}$ to $100^{\circ} \mathrm{C}$ ), discarding the first and the last extracted portion of juice. Glass bottles of $1.5 \mathrm{~L}$ were used. They were previously sanitized with chlorinated water and later kept in boiling water until the bottling. Immediately after bottling, the bottles were closed with a plastic screw cap and kept with the bottleneck down. The samples were kept under refrigeration until analysis.

The experimental design was completely randomized, with three replications. The treatments were arranged in a two-factorial scheme, including the varieties (Cabernet Sauvignon, Merlot and Chardonnay) and the maturation stages (15, 17 and $19{ }^{\circ}$ Brix). Three bottles were used for each variety at each collection point, where each bottle represented a repetition, totaling nine bottles per variety for physicochemical analyses.

\subsection{Physicochemical Analysis}

The physicochemical analyses of titratable acidity (TA), soluble solids (SS), relative density, total sugars, alcohol, volatile acidity and SS/TA ratio were performed at the Epagri Station, Agricultural Research and Extension Company of Santa Catarina, Estação Experimental de Videira (Videira, SC/Brazil). The analyses were carried out according to the methodologies of the Ministry of Agriculture [9].

To determine the titratable acidity, $10 \mathrm{~mL}$ of juice was homogenized in $100 \mathrm{~mL}$ of distilled water, added with 2-3 drops of phenolphthalein, and this dilution was titrated with $\mathrm{NaOH}$ solution $(0.1 \mathrm{~N})$ until pink 


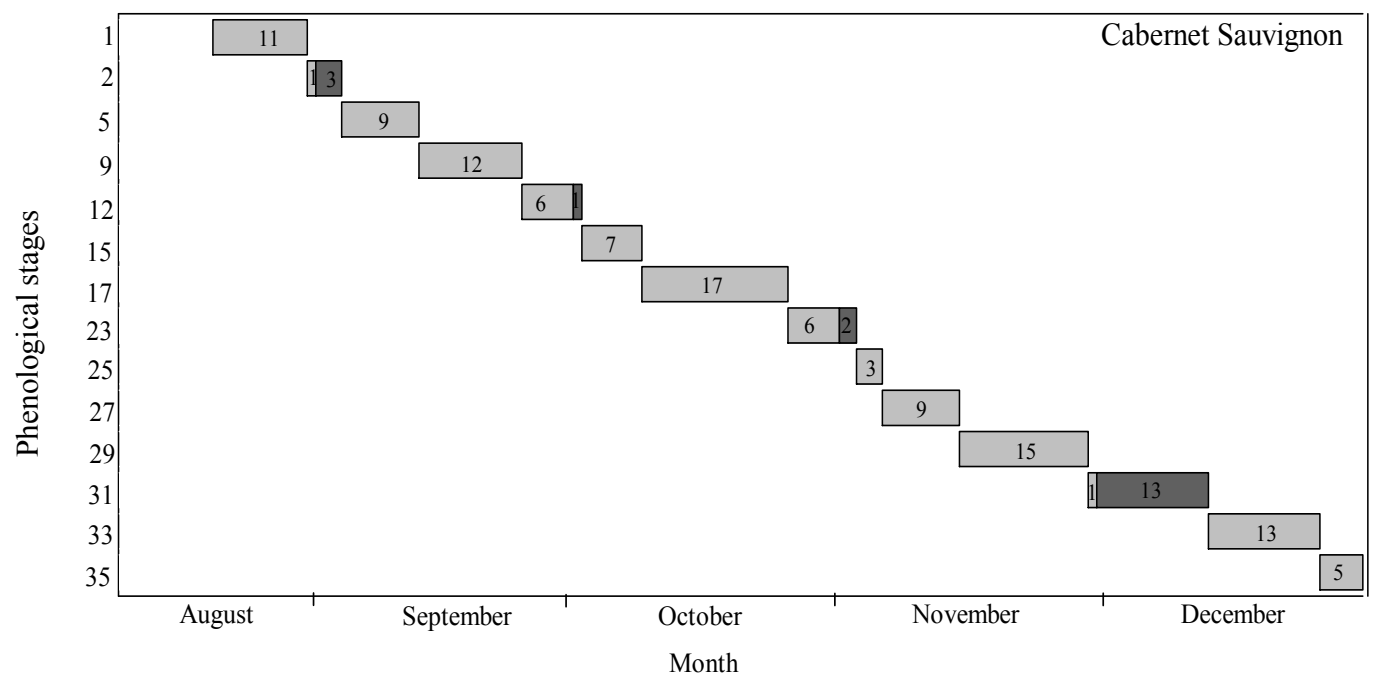

(a)

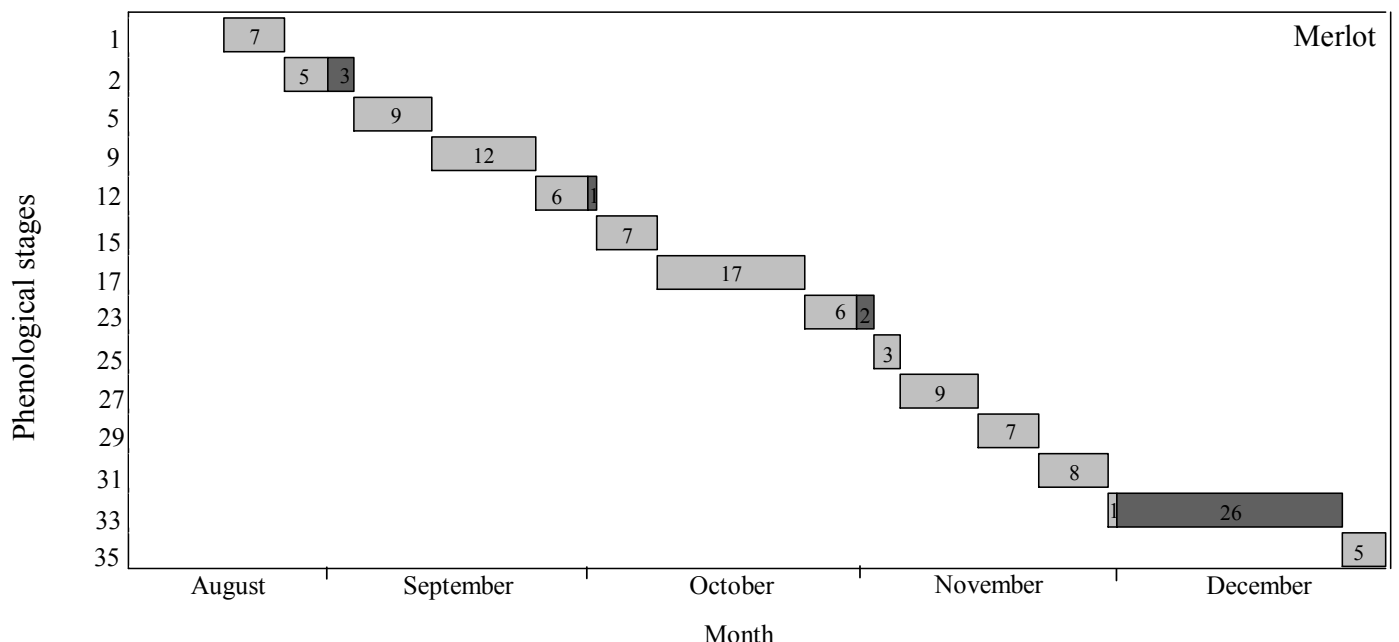

(b)

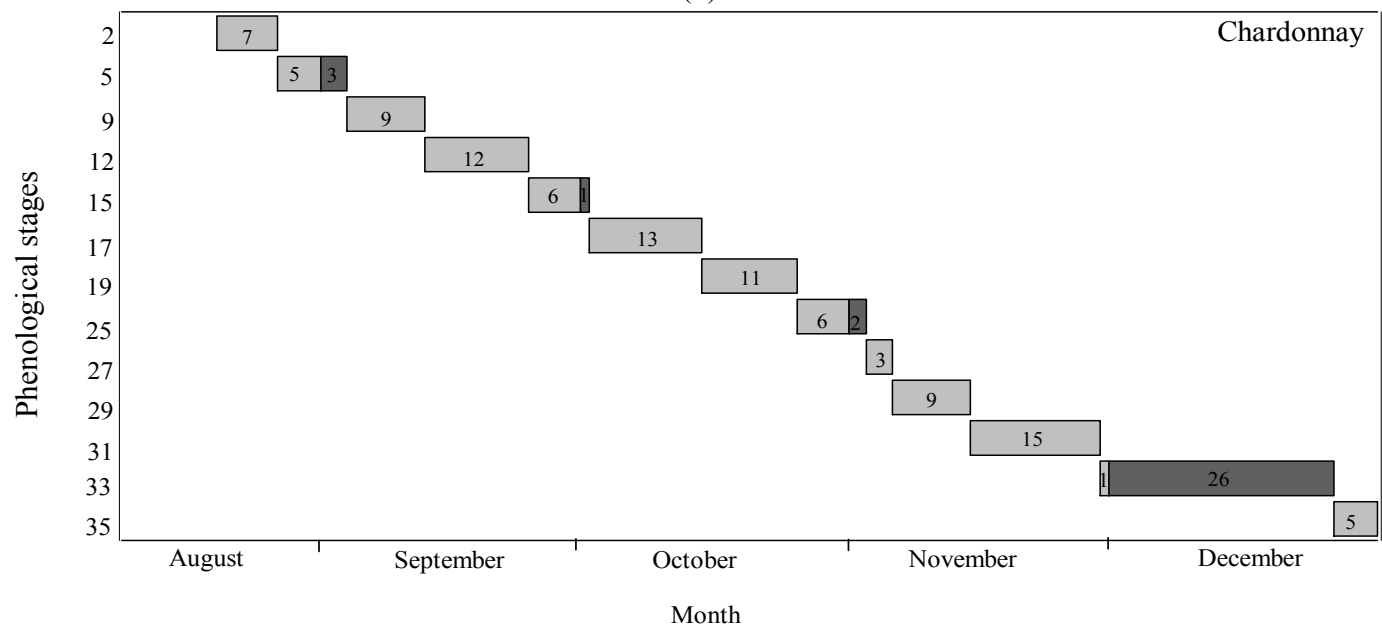

(c)

Fig. 2 Phenological monitoring of the varieties Cabernet Sauvignon (a), Merlot (b) and Chardonnay (c) to define the maturation stages.

1st harvest: $15^{\circ}$ Brix; 2nd harvest: $17^{\circ}$ Brix; 3rd harvest: $19^{\circ}$ Brix.

The phenological stages were determined according to the phenological scale system of Eichhorn and Lorenz [8]. 
(turning point). The results were expressed as $\mathrm{g} / 100 \mathrm{~g}$ of tartaric acid.

The results of soluble solids were expressed in ${ }^{\circ}$ Brix, the relative density expressed in $\mathrm{cm}^{3}$, total sugars expressed in $\mathrm{g} / 100 \mathrm{~g}$, alcoholic content expressed in $\mathrm{v} / \mathrm{v}$ and volatile acidity in $\mathrm{g} 100 / \mathrm{g}$ of acetic acid were determined by an electronic enologic distiller $\left(\right.$ Gibertini $\left.^{\circledR}\right)$, which was calibrated with distilled water, and then placed on the samples, thus obtaining the readings. The SS/TA ratio was obtained through the quotient between soluble solids and titratable acidity.

\subsection{Statistical Analysis}

The data obtained were analyzed for normality by the Shapiro Wilk test, homoscedasticity by Hartley test and the independence of residues by graphic analysis. Subsequently, the data were submitted to analysis of variance through the $F$ test $(P \leq 0.05)$. Being statistically significant, the effects of the varieties were compared by the Duncan test $(P \leq 0.05)$ and maturation stages by linear regression models $(P$ $\leq 0.05)$ as Eq. (1):

$$
y=y_{0}+a x
$$

where, $y=$ response variable; $y_{o}=$ response variable corresponding to the minimum or maximum point of the curve; $a=$ slope of the line or curve; $x=$ degrees in ${ }^{\circ}$ Brix.

The selection of the model was based on low residue, low $P$ value, and high $R^{2}$ and $R_{\text {adj }}^{2}$ (the adequacy of determination coefficient $R^{2}$ ). The presence of correlations between the dependent variables of the study was analyzed through the Pearson correlation coefficient in general for the whole experiment, as well as individualized for the varieties at each stage of maturation.

\section{Results}

\subsection{Physicochemical Analyses}

The assumptions of the mathematical model were all met and data transformation was not necessary for all variables. The titratable acidity analyses $(F=12.41$, $P<0.0001)$, soluble solids $(F=6.52, P=0.0020)$, SS/TA ratio $(F=15.18, P<0.0001)$, relative density $(F=7.04, P=0.0014)$, total sugars $(F=10.37, P=$ $0.0002)$ and volatile acidity $(F=5.55, P=0.0048)$ showed significance in the interaction between the treatment factors tested. For the alcohol variable, there was neither significance for the variety effect $(F=$ $1.88, P=0.1883)$, maturation stage $(F=0.49, P=$ $0.6204)$ nor for the interaction between the treatment factors $(F=0.09, P=0.9834)$ (Table 1$)$.

\subsubsection{Titratable Acidity}

For titratable acidity, at the maturation stage of $15{ }^{\circ}$ Brix, significant differences were observed between the juices from the Chardonnay variety, which obtained the highest values, in relation to the other juices. For $17{ }^{\circ}$ Brix, Cabernet Sauvignon differed from the others with the lowest values. Whereas at $19{ }^{\circ}$ Brix, the behavior was the same as that at $15{ }^{\circ}$ Brix (Table 1). The titratable acidity content is regulated by law with a minimum value of $0.41 \mathrm{~g} / 100 \mathrm{~g}$ in tartaric acid, so all juices met the requirement at different maturation points [10].

The titratable acidity data were adjusted to the linear regression model for Cabernet sauvignon $(F=$ 21.2138, $P=0.0025)$, Merlot $(F=43.9187, P=$ $0.0003)$ and Chardonnay $(F=253.2303, P<0.0001)$, respectively (Fig. 3a). Decreases in titratable acidity values of $21.6 \%$ and $43.1 \%$ were observed for Cabernet Sauvignon for $17^{\circ}$ Brix and $19{ }^{\circ}$ Brix, respectively, when compared to $15{ }^{\circ}$ Brix. For the juices obtained from the Merlot variety, the percentages decreases were similar to Cabernet Sauvignon, being $23.4 \%$ and $46.8 \%$ for the same comparisons. The highest percentages decreases were observed for Chardonnay, $29.7 \%$ and $59.5 \%$ for $17{ }^{\circ}$ Brix and $19{ }^{\circ}$ Brix, respectively, when compared to $15^{\circ}$ Brix.

\subsubsection{Soluble Solids}

The juice of the Merlot variety presented a 
significant difference for the soluble solids content at the $15^{\circ}$ Brix maturation point, presenting the highest average in relation to the other processed juices. At the $17{ }^{\circ}$ Brix maturation point, there was a significant difference between the variety, with the highest mean being Cabernet Sauvignon, followed by Chardonnay and Merlot. However, at $19{ }^{\circ}$ Brix, there was no significant difference between the different processed juices (Table 1). According to legal standards, the soluble solids content of whole grape juice must be at least $14.0{ }^{\circ}$ Brix [10]. At the $15{ }^{\circ}$ Brix point, none of the analyzed juices met the specification of the legislation, and at point $17{ }^{\circ}$ Brix, only the Cabernet
Sauvignon juice was in line with the recommended value. At $19{ }^{\circ}$ Brix, all the juices presented similar behavior, according to the identity and quality standards for the soluble solids variable. The data for this variable were adjusted appropriately to the linear regression model for Cabernet Sauvignon $(F=15.3412$, $P=0.0058)$, Merlot $(F=19.0876, P=0.0033)$ and Chardonnay $(F=31.2046, P=0.0008)$ (Fig. 3b). Increases were observed in the soluble solids content in Cabernet Sauvignon of $7.8 \%$ for $17{ }^{\circ}$ Brix and $15.5 \%$ for $19{ }^{\circ}$ Brix when confronted with the initial maturation point of $15^{\circ}$ Brix. For the Merlot juice, in the same comparison, increases were lower than

Table 1 Physicochemical variables of grape juice of the varieties Cabernet Sauvignon, Merlot and Chardonnay over three maturity stages.

\begin{tabular}{|c|c|c|c|}
\hline \multirow{2}{*}{ Variety } & \multicolumn{3}{|c|}{ Maturation stage ( ${ }^{\circ}$ Brix) } \\
\hline & 15 & 17 & 19 \\
\hline & \multicolumn{3}{|c|}{ Titratable acidity $(\mathrm{g} / 100 \mathrm{~g}$ tartaric acid) } \\
\hline Cabernet Sauvignon & $1.04 \pm 0.00^{\mathrm{b}}$ & $0.59 \pm 0.01^{\mathrm{b}}$ & $0.58 \pm 0.01^{\mathrm{a}}$ \\
\hline Merlot & $1.01 \pm 0.06^{\mathrm{b}}$ & $0.71 \pm 0.03^{\mathrm{a}}$ & $0.58 \pm 0.01^{\mathrm{a}}$ \\
\hline \multirow[t]{2}{*}{ Chardonnay } & $1.24 \pm 0.01^{\mathrm{a}}$ & $0.79 \pm 0.02^{\mathrm{a}}$ & $0.52 \pm 0.01^{\mathrm{b}}$ \\
\hline & \multicolumn{3}{|c|}{ Soluble solids $\left({ }^{\circ}\right.$ Brix $)$} \\
\hline Cabernet Sauvignon & $12.40 \pm 0.10^{\mathrm{b}}$ & $14.37 \pm 0.09^{\mathrm{a}}$ & $14.37 \pm 0.32^{\mathrm{a}}$ \\
\hline Merlot & $13.20 \pm 0.06^{\mathrm{a}}$ & $13.27 \pm 0.13^{\mathrm{c}}$ & $14.73 \pm 0.18^{\mathrm{a}}$ \\
\hline \multirow[t]{2}{*}{ Chardonnay } & $12.17 \pm 0.20^{\mathrm{b}}$ & $13.73 \pm 0.09^{\mathrm{b}}$ & $14.40 \pm 0.40^{\mathrm{a}}$ \\
\hline & \multicolumn{3}{|c|}{ SS/TA ratio } \\
\hline Cabernet Sauvignon & $11.95 \pm 0.11^{\mathrm{a}}$ & $24.50 \pm 0.43^{\mathrm{a}}$ & $24.64 \pm 0.66^{\mathrm{a}}$ \\
\hline Merlot & $13.17 \pm 0.82^{\mathrm{a}}$ & $18.69 \pm 1.01^{\mathrm{b}}$ & $25.43 \pm 0.80^{\mathrm{a}}$ \\
\hline \multirow[t]{2}{*}{ Chardonnay } & $9.79 \pm 0.16^{\mathrm{b}}$ & $17.41 \pm 0.57^{\mathrm{b}}$ & $27.56 \pm 1.21^{\mathrm{a}}$ \\
\hline & \multicolumn{3}{|c|}{ Relative density $\left(\mathrm{g} / \mathrm{cm}^{3}\right)$} \\
\hline Cabernet Sauvignon & $1.050 \pm 0.00^{\mathrm{b}}$ & $1.060 \pm 0.00^{\mathrm{a}}$ & $1.060 \pm 0.00^{\mathrm{a}}$ \\
\hline Merlot & $1.060 \pm 0.00^{\mathrm{a}}$ & $1.046 \pm 0.00^{\mathrm{c}}$ & $1.060 \pm 0.00^{\mathrm{a}}$ \\
\hline \multirow[t]{2}{*}{ Chardonnay } & $1.049 \pm 0.00^{\mathrm{b}}$ & $1.059 \pm 0.00^{\mathrm{b}}$ & $1.060 \pm 0.00^{\mathrm{a}}$ \\
\hline & \multicolumn{3}{|c|}{ Total sugars $(\mathrm{g} / 100 \mathrm{~g})$} \\
\hline Cabernet Sauvignon & $10.63 \pm 0.09^{\mathrm{b}}$ & $12.30 \pm 0.07^{\mathrm{a}}$ & $12.33 \pm 0.25^{\mathrm{a}}$ \\
\hline Merlot & $11.33 \pm 0.03^{\mathrm{a}}$ & $11.40 \pm 0.10^{\mathrm{c}}$ & $12.57 \pm 0.18^{\mathrm{a}}$ \\
\hline \multirow[t]{2}{*}{ Chardonnay } & $10.43 \pm 0.18^{\mathrm{b}}$ & $11.77 \pm 0.07^{\mathrm{b}}$ & $13.00 \pm 0.30^{\mathrm{a}}$ \\
\hline & \multicolumn{3}{|c|}{ Volatile acidity (g/100 g acetic acid) } \\
\hline Cabernet Sauvignon & $0.009 \pm 0.00^{\mathrm{a}}$ & $0.01 \pm 0.00^{\mathrm{a}}$ & $0.01 \pm 0.00^{\mathrm{a}}$ \\
\hline Merlot & $0.01 \pm 0.00^{\mathrm{a}}$ & $0.009 \pm 0.00^{\mathrm{b}}$ & $0.01 \pm 0.00^{\mathrm{a}}$ \\
\hline \multirow[t]{2}{*}{ Chardonnay } & $0.01 \pm 0.00^{\mathrm{a}}$ & $0.01 \pm 0.00^{\mathrm{a}}$ & $0.009 \pm 0.00^{\mathrm{b}}$ \\
\hline & \multicolumn{3}{|c|}{ Alcohol content $(\%)^{\mathrm{NS}}$} \\
\hline Cabernet Sauvignon & $0.10 \pm 0.10$ & $0.23 \pm 0.12$ & $0.17 \pm 0.09$ \\
\hline Merlot & $0.00 \pm 0.00$ & $0.05 \pm 0.05$ & $0.00 \pm 0.00$ \\
\hline Chardonnay & $0.10 \pm 0.10$ & $0.13 \pm 0.09$ & $0.10 \pm 006$ \\
\hline
\end{tabular}

${ }^{\mathrm{a}-\mathrm{c}}$ Mean \pm standard error accompanied by the same lowercase letter in the column did not differ by Duncan test $(P \leq 0.05)$ comparing the varieties at each maturation stage; ${ }^{\text {NS}}$ : not significantly different by the $F$ test $(P \leq 0.05)$. 
Cabernet Sauvignon, being $5.9 \%$ and $11.8 \%$ for $17^{\circ}$ Brix and $19^{\circ}$ Brix, respectively. In relation to the Chardonnay juice, the increases were higher than the others mentioned above, being $9 \%$ and $18.2 \%$ for $17{ }^{\circ}$ Brix and $19{ }^{\circ}$ Brix, respectively, when compared to $15^{\circ}$ Brix.

\subsubsection{SS/TA}

For the variable SS/TA, the Chardonnay juice presented significant difference at $15^{\circ}$ Brix maturation point, due to the lower average obtained. Cabernet Sauvignon obtained a difference from the others, presenting the highest average in the maturation point $17{ }^{\circ}$ Brix, followed by Merlot and Chardonnay. However, at $19{ }^{\circ}$ Brix, there were no significant differences between the varieties tested (Table 1).

The values obtained for the $15{ }^{\circ}$ Brix harvest point were below the limits established by the legislation, which is between 15 and 45 . At the $17{ }^{\circ}$ Brix harvesting point, all the juices met the legislation requirements, while Chardonnay and Merlot were very close to the minimum, showing that these juices have considerable acidity. In the grapes at $19{ }^{\circ}$ Brix, the values remained similar among the varieties tested, being in agreement with Choudhury [11], who considered the value to be equal to or greater than 20 . Rizzon and Link [12] found a value of 18 for SS/TA in Cabernet Sauvignon grape juice, below that of the same variety at harvesting points $17{ }^{\circ}$ Brix and $19^{\circ}$ Brix.

The SS/TA ratio data were appropriately fit to the linear regression model for Cabernet Sauvignon $(F=$ 20.9122, $P=0.0026)$, Merlot $(F=106.6346, P=$ $0.0001)$ and Chardonnay $(F=236.3966, P<0.0001)$ (Fig. 3c). Increases were observed when comparing the maturation points of $17{ }^{\circ} \mathrm{Brix}$ and $19{ }^{\circ} \mathrm{Brix}$ in relation to $15{ }^{\circ} \mathrm{Brix}$. The values of the percentages were $45.4 \%$ for $17{ }^{\circ}$ Brix and $90.7 \%$ for $19{ }^{\circ}$ Brix. Merlot and Chardonnay presented greater increases for this same comparison. $47.2 \%$ and $94.2 \%$ was obtained for Merlot, and $95.2 \%$ and $190.4 \%$ for Chardonnay, for $17^{\circ}$ Brix and $19{ }^{\circ}$ Brix, respectively.
The analyzed juices presented increasing percentages when comparing the $17^{\circ} \mathrm{Brix}$ and $19^{\circ} \mathrm{Brix}$ points with $15^{\circ} \mathrm{Brix}$, however, it is possible to verify that for the variety Cabernet Sauvignon; the difference between $17^{\circ}$ Brix and $19^{\circ}$ Brix is relatively small, the others presented opposite behavior.

\subsubsection{Relative Density}

For the relative density at the $15{ }^{\circ}$ Brix maturation point, the juice of the Merlot variety showed significant differences obtaining the highest average, in relation to the other juices. For $17^{\circ}$ Brix, there was a difference between the three analyzed juices, with Cabernet Sauvignon holding the highest average, followed by Chardonnay and Merlot. At $19{ }^{\circ}$ Brix, there was no significant difference between grape types (Table 1).

The density of the grape juice should be at least $1.057 \mathrm{~g} / \mathrm{cm}^{3}$ [10]. At $15^{\circ}$ Brix, Cabernet Sauvignon and Chardonnay values were lower than those defined by law, at $17^{\circ}$ Brix the behavior was the reverse of the previous harvest point, and at $19{ }^{\circ}$ Brix, all juices remained above the minimum required.

The relative density data were appropriately fit to the linear regression model for Cabernet Sauvignon ( $F$ $=17.6937, P=0.0040)$, Merlot $(F=13.4919, P=$ $0.0079)$ and Chardonnay $(F=96.1785, P<0.0001)$ (Fig. 3d). When comparing the maturation points $17^{\circ}$ Brix and $19^{\circ}$ Brix with $15^{\circ}$ Brix, increases of $0.4 \%$ and $0.8 \%$, respectively, were observed for Cabernet Sauvignon. These values were repeated for Merlot, for the same comparison. In the case of the Chardonnay variety, the increases were slightly higher, being $0.6 \%$ for $17{ }^{\circ}$ Brix and $1.2 \%$ for $19{ }^{\circ}$ Brix. In the same way as the soluble solids content, the density had a significant linear increase, since it has direct relation with the sugar concentration in the must and can be diluted by the water vapor used in the extraction method.

\subsubsection{Total Sugars}

The total sugars showed a significant difference for the Merlot variety with the highest average at the 
$15{ }^{\circ}$ Brix harvest point. At $17{ }^{\circ}$ Brix, there was a significant difference for all varieties tested, the highest average being Cabernet Sauvignon, followed by Chardonnay and Merlot. At $19^{\circ}$ Brix, there was no significant difference between grape types (Table 1). The Brazilian legislation establishes a maximum value for total sugars of $20 \mathrm{~g} / \mathrm{L}$ [10], so all processed juices, regardless of the maturation point, met the defined limit.

The total sugar content data were appropriately fit to the linear regression model for Cabernet Sauvignon $(F=14.9148, P=0.0062)$, Merlot $(F=18.6078, P=$ $0.0035)$ and Chardonnay $(F=88.8715, P<0.0001)$ (Fig. 3e). Increases were observed in the values of total sugars, where Cabernet Sauvignon presented 7.7\% and $15.4 \%$ for $17{ }^{\circ}$ Brix and $19{ }^{\circ}$ Brix, respectively, when compared with the $15^{\circ}$ Brix harvest point. For the juice obtained from the Merlot variety, the percentage increases were $5.5 \%$ and $11.1 \%$ for the same comparisons. For Chardonnay, the highest percentage increases of $12.3 \%$ and $24.6 \%$ were observed for $17{ }^{\circ}$ Brix and $19{ }^{\circ}$ Brix, respectively, when compared to $15^{\circ}$ Brix.

\subsubsection{Volatile Acidity}

For the volatile acidity variable, there was no statistical difference between the varieties at the $15^{\circ}$ Brix harvest point. At $17^{\circ} \mathrm{Brix}$, the Merlot variety differed from the others, presenting a lower mean. At $19{ }^{\circ}$ Brix, the Chardonnay variety showed the same behavior as the Merlot variety at the stated harvesting point, differing from the others (Table 1). The volatile acidity data were appropriately fit to the linear regression model only for Cabernet Sauvignon $(F=$ 17.6842, $P=0.0040)$. For Merlot and Chardonnay, no equation adjustments were observed (Fig. 3f), with increases of $13.9 \%$ and $27.7 \%$ being observed for $17^{\circ}$ Brix and $19^{\circ}$ Brix, respectively, when compared to $15^{\circ}$ Brix.

\subsection{Correlations}

The correlations (Table 2), which were generally verified for the whole experiment, between the dependent variables were positive or negative. There were negative correlations between titratable acidity and soluble solids $(r=-0.89, P<0.0001), \mathrm{SS} / \mathrm{TA}$ ratio $(r=-0.97, P<0.0001)$, relative density $(r=-0.88, P<$ $0.0001)$ and total sugars $(r=-0.90, P<0.0001)$, showing that the increase in titratable acidity resulted in decreases in soluble solids values, and consequently in the SS/TA ratio, relative density and total sugars.

Positive correlations occurred between soluble solids with SS/TA ratio $(r=0.93, P<0.0001)$, density $(r=0.90, P<0.0001)$ and total sugars $(r=0.90, P<$ 0.0001). Correlations between SS/TA ratio with relative density $(r=0.92, P<0.0001)$ and total sugars $(r=0.93, P<0.0001)$ also occurred, as well as positive correlations between relative density with total sugars $(\mathrm{r}=0.97, P<0.0001)$ (Table 2). These correlations showed that as the soluble solids content and SS/TA ratio were higher, the other abovementioned variables obtained were proportional increase.

In the Cabernet Sauvignon variety for the maturation stage of $15^{\circ}$ Brix, there was a positive correlation of relative density with total sugars $(r=$ $0.99, P=0.05)$. For the maturation stage of $17^{\circ}$ Brix, titratable acidity with volatile acidity $(r=0.99, P<$ 0.0001) obtained a positive correlation. In the $19{ }^{\circ}$ Brix maturation stage, correlation only occurred between soluble solids and total sugars $(r=0.99, P=$ $0.01)$.

In the Merlot variety at the $15^{\circ}$ Brix maturation stage, negative correlations were observed between titratable acidity with $\mathrm{SS} / \mathrm{TA}$ ratio $(r=-0.99, P=$ 0.004 ) and positive correlations between soluble solids and relative density $(r=0.99, P<0.0001)$. In the maturation stage of $17{ }^{\circ}$ Brix, a negative correlation of titratable acidity with soluble solids $(r=$ $-0.99, P<0.0001)$ was also observed. While positive correlation of soluble solids with SS/TA ratio $(r=$ $0.99, P<0.0001)$ and total sugars $(r=0.99, P<$ $0.0001)$, and SS/TA ratio with total sugars $(r=0.99$, $P<0.0001)$ were observed. At the $19{ }^{\circ}$ Brix maturation 


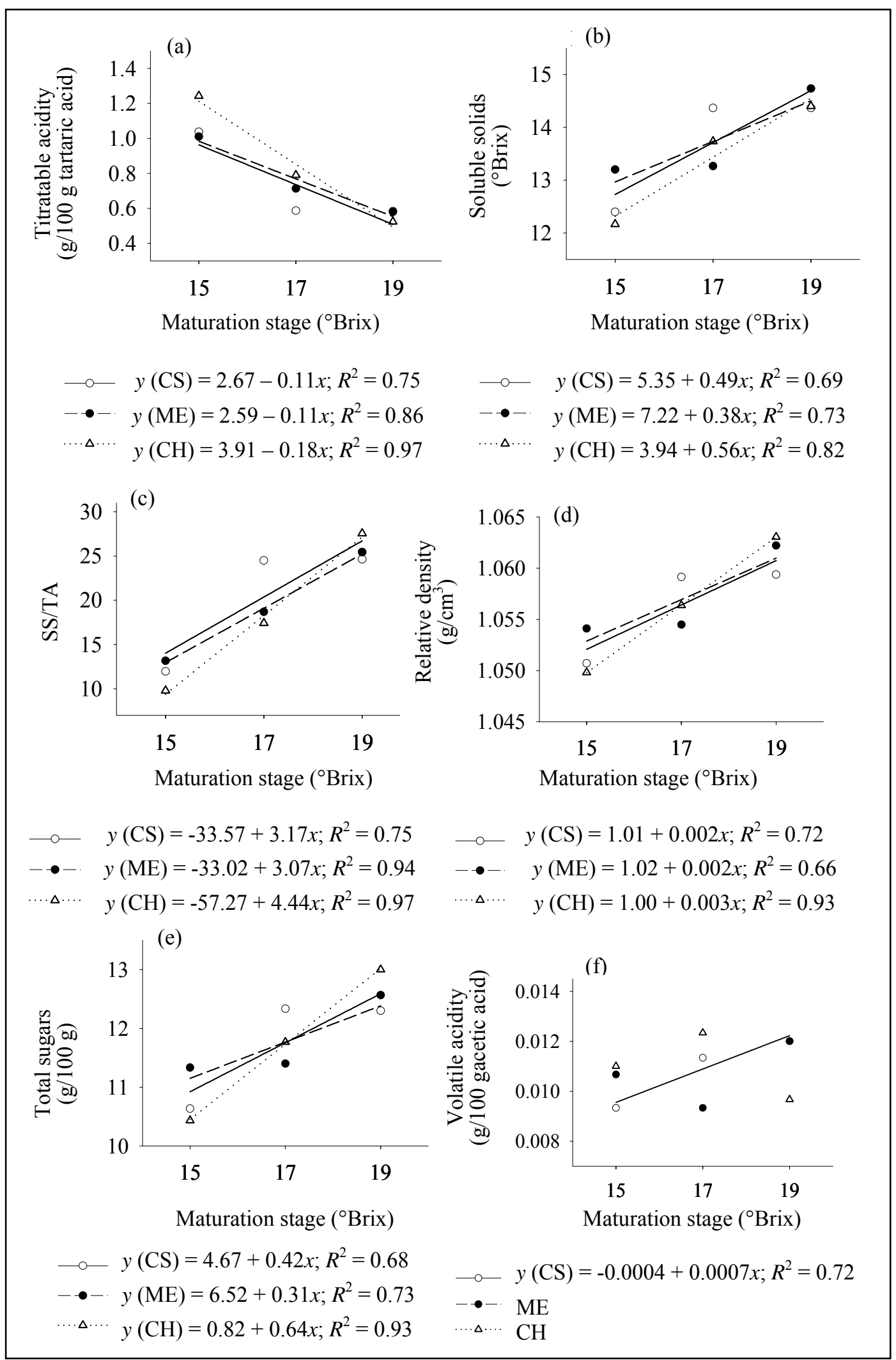

Fig. 3 Titratable acidity (a), soluble solids (b), SS/TA ratio (c), relative density (d), total sugars (e) and volatile acidity (f) of grape juice of Cabernet Sauvignon (CS), Merlot (ME) and Chardonnay (CH) over three stages of maturation. 
Table 2 Pearson correlation coefficients and $P$ values of the dependent variables of different varieties of grape juice over three maturity stages.

\begin{tabular}{|c|c|c|c|c|c|c|c|}
\hline $\begin{array}{l}\text { Dependent } \\
\text { Variables }\end{array}$ & $\begin{array}{l}\text { Titratable acidity } \\
\text { (1) }\end{array}$ & $\begin{array}{l}\text { Soluble solids } \\
(2)\end{array}$ & $\begin{array}{l}\text { SS/TA ratio } \\
\text { (3) }\end{array}$ & $\begin{array}{l}\text { Relative } \\
\text { density (4) }\end{array}$ & $\begin{array}{l}\text { Total sugars } \\
\text { (5) }\end{array}$ & $\begin{array}{l}\text { Volatile acidity } \\
\text { (6) }\end{array}$ & $\begin{array}{l}\text { Alcohol } \\
\text { (7) }\end{array}$ \\
\hline 1 & 1.000 & $\begin{array}{l}-0.889^{*} \\
<0.0001 * *\end{array}$ & $\begin{array}{l}-0.968 \\
<0.0001\end{array}$ & $\begin{array}{l}-0.878 \\
<0.0001\end{array}$ & $\begin{array}{l}-0.896 \\
<0.0001\end{array}$ & $\begin{array}{l}-0.207 \\
0.309\end{array}$ & $\begin{array}{l}-0.136 \\
0.535\end{array}$ \\
\hline 2 & & 1.000 & $\begin{array}{l}0.926 \\
<0.0001\end{array}$ & $\begin{array}{l}0.900 \\
<0.0001\end{array}$ & $\begin{array}{l}0.902 \\
<0.0001\end{array}$ & $\begin{array}{l}0.374 \\
0.060\end{array}$ & $\begin{array}{l}0.099 \\
0.650\end{array}$ \\
\hline 3 & & & 1.000 & $\begin{array}{l}0.918 \\
<0.0001\end{array}$ & $\begin{array}{l}0.926 \\
<0.0001\end{array}$ & $\begin{array}{l}0.208 \\
0.307\end{array}$ & $\begin{array}{l}0.137 \\
0.533\end{array}$ \\
\hline 4 & & & & 1.000 & $\begin{array}{l}0.973 \\
<0.0001\end{array}$ & $\begin{array}{l}0.237 \\
0.244\end{array}$ & $\begin{array}{l}0.048 \\
0.828\end{array}$ \\
\hline 5 & & & & & 1.000 & $\begin{array}{l}0.213 \\
0.296\end{array}$ & $\begin{array}{l}0.100 \\
0.649\end{array}$ \\
\hline 6 & & & & & & 1.000 & $\begin{array}{l}0.173 \\
0.441\end{array}$ \\
\hline 7 & & & & & & & 1.000 \\
\hline
\end{tabular}

* Pearson correlation coefficient; **P values.

stage, the negative correlation occurred between $\mathrm{SS} / \mathrm{TA}$ ratio and titratable acidity $(r=-0.99, P=0.03)$. The SS/TA ratio is given by the value of soluble solids divided by the value of titratable acidity. Higher values of titratable acidity result in smaller values for the SS/TA ratio, characterizing more acidic juices. The more pronounced acidity at the $19{ }^{\circ}$ Brix harvest point for the Merlot variety can be explained by the fact that the transformations occurring in the grapes during maturation do not occur simultaneously, and concentration of sugar may occur without decreasing the acid concentration [13].

Considering the Chardonnay variety at the $15{ }^{\circ}$ Brix maturation stage, only correlation between relative density and total sugars $(r=0.99, P=0.008)$ was observed. In this same variety, the correlation was verified between relative density and soluble solids $(r$ $=0.99, P=0.04$ ) at maturation stage of $17^{\circ}$ Brix. At the maturation stage of $19{ }^{\circ}$ Brix, no significant correlations were found between the dependent variables studied.

The correlation of the dependent variables observed in all juices under study along the maturation points shows that there is an increase in the content of soluble solids, also an increase in total sugars, relative density and SS/TA ratio. As for titratable acidity, it can be observed that as higher values presented, the correlations with the aforementioned variables are negative, showing that their evolution occurs in the opposite way.

\section{Discussion}

The titratable acidity decreased significantly over the different maturation points. The three varieties tested had similar behavior during maturation, differing only in the observed percentages. The decrease in the concentration of the organic acids during the evolution of the maturation is due to the dilution of the must by the entrance of water in the fruit, transported in the xylem by the mobilization of bases that neutralize the organic acids and by the respiratory process [14]. The phenomenon of respiration suffers influence with temperature and rainfall, so years of hot and dry summers characterize less acidic grapes [13]. The highest averages obtained by Chardonnay, followed by Merlot, may be related to the higher temperature and lower rainfall levels during the month of January (Figs. $1 \mathrm{~b}$ and 1c), which coincided with most of the harvests for these varieties, while Cabernet Sauvignon had its last two harvests in February (Fig. 1a), which was characterized as a rainy month in the municipality of São Lourenço do Sul in 2015.

Similar to the titratable acidity, the soluble solids content is influenced by climatic factors. When high temperatures and sunshine prevail, vine metabolism 
favors a greater accumulation of soluble solids in the grape berry [15]. The method of juice preparation may influence the difference observed in the value of soluble solids of the grape in relation to the juice. These variations may be due to the dilution caused by the incorporation of water generated by the steam used in the heating to extract the coloring matter from the berries [12]. Dutra et al. [16] found higher values of $15.4{ }^{\circ}$ Brix and $16.4{ }^{\circ}$ Brix for juices made from Cabernet Sauvignon and Tempranillo, but in the same study, Syrah juice had a lower value of $13{ }^{\circ}$ Brix. The authors also associated their results with the possible dilution caused by the preparation method.

The total sugars of the whole juice originate exclusively from the grape that gave rise to it. In general, Vitis vinifera cultivars have a higher sugar production potential than American Vitis labrusca grapes $[17,18]$. The sugars produced in the grape vary between cultivars and environmental conditions [19]. The health status of the grapevine, mainly diseases that attack the leaves, causing early defoliation influence in a lower accumulation of sugars in the berries, since most of them come from the leaves in the form of sucrose and later it is transformed into fructose and glucose in the berries [19]. Increases were observed in the total sugar content at harvest points $17^{\circ}$ Brix and $19^{\circ}$ Brix in relation to the $15{ }^{\circ}$ Brix harvest point. When comparing the averages of the three harvest points, it is possible to verify that this increase was relatively small, especially for Cabernet Sauvignon between $17^{\circ}$ Brix and $19{ }^{\circ}$ Brix. These results may be reflective of the severe attack of downy mildew that led to the loss of leaves in advance. This fact occurred between the end of January and beginning of February, coinciding with the maturation period of the grapes, which reflected in a low sugar content accumulated in the berries. It was more severe for Cabernet Sauvignon, since it had its last two harvests in the second half of February (Fig. 1a).

A linear increase in volatile acidity was observed only in the grape juice of Cabernet Sauvignon, probably due to the sanitary state of the grape by the attack of mildew, evidenced in the last harvests. However, the values are low, but are within the limits established by Brazilian legislation, which is 0.50 $\mathrm{g} / 100 \mathrm{~g}$ [10]. Dutra et al. [16] found values of 0.15 $\mathrm{g} / 100 \mathrm{~g}$ in acetic acid for Cabernet Sauvignon and Syrah and $0.12 \mathrm{~g} / 100 \mathrm{~g}$ in acetic acid for Tempranillo, arguing that the low values show good sanitary status of the grapes used in the experiment. Rizzon and Link [12] observed higher values for volatile acidity in juices from Cabernet Sauvignon, when compared to American varieties, reaching $0.2 \mathrm{~g} / 100 \mathrm{~g}$ in acetic acid, the authors also associated the highest value to the sanitary state of the grape.

\section{Conclusions}

Three Vitis vinifera varieties (Cabernet Sauvignon Merlot and Chardonnay) were tested for juice at different ripening stages 15, 17 and $19{ }^{\circ}$ Brix. The juices showed a decrease in the titratable acidity and increase in the other physicochemical variables tested along the different harvest points. All tested varieties were suitable for juice production, and the harvest point of $19{ }^{\circ}$ Brix received the best sensorial acceptance by the evaluators.

\section{References}

[1] Pinheiro, É. S., Costa, J. M. C., Clemente, E., Machado, P. H. S., and Maia, G. A. 2009. "Physical-Chemical and Mineral Stability of Grape Juice Obtained by Steam Extraction." Journal of Agronomic Science (Fortaleza) 40 (3): 373-80. (in Portuguese)

[2] Rizzon, L. A., Manfroi, V., and Meneguzzo, J. 1998. "Elaboration of Grape Juice in the Vineyard Property." Technical Circular No. 21, Embrapa Uva e Vinho, Bento Gonçalves. Accessed December 3, 1999. https://www.infoteca.cnptia.embrapa.br/handle/doc/5384 70. (in Portuguese)

[3] Sachi, A. D. T., and Biasi, L. A. 2008. "Maturation of Four Cultivars of Muscadine Grapes in Pinhais, PN." Scientia Agraria 9 (2): 255-60. (in Portuguese)

[4] Guerra, C. G., Mandelli, F., Tonietto, J., Zanus, M. C., and Camargo, U. A. 2009. Knowing the Essentials about Grapes and Wines. Bento Gonçalves: Embrapa Grape and Wine, 69. (in Portuguese) 
[5] Köppen, W., and Geiger, R. 1928. Climates of the Earth. Gotha: Justus Perthes. (in German)

[6] Cunha, N. G., Silveira, R. J. C., and Severo, C. R. S. 2006. Soil Study of São Lourenço do Sul-RS. Pelotas: Embrapa Clima Temperado. (in Portuguese)

[7] Embrapa National Soil Research Center. 2006. Brazilian System of Soil Classification, 2nd ed.. Rio de Janeiro: Embrapa Soils, 306. (in Portuguese)

[8] Eichhorn, K. W., and Lorenz, D. H. 1977. "Phenological Development Stages of the Grape Vine." Nachrichtenblatt des Deutschen Pflanzenschutzdienstes 29 (8): 119-20. (in German)

[9] Ministry of Agriculture. 2014. "Methods of BEV/IQA Area." Accessed on March, 2015. http://www.agricultura.gov.br/portal/page/portal/Internet MAPA/paginainicial/laboratorios/metodos/metodos-da-ar ea-BEV-IQA. (in Portuguese)

[10] Brasil Ministry of Health. Secretariat of Health Surveillance. 2004. "Complementation of the Identity and Quality Standards of Wine and Grape and Wine Derivatives." Ordinance No. 55, Official Journal of the Union, Brasília. Accessed July 30, 2004. https://www.jusbrasil.com.br/diarios/674051/pg-4-secao-1diario-oficial-da-uniao-dou-de-30-07-2004. (in Portuguese)

[11] Choudhury, M. M., ed. 2001. Table Grape: Postharvest. Brasília: Embrapa Technological Information. (in Portuguese)

[12] Rizzon, L. A., and Link, M. 2006. "Composition of the Homemade Juice of Different Cultivars." Rural Science
36 (2): 689-92. (in Portuguese)

[13] Tomaz, F. O. N. 2013. "Study of the Evolution of Grape Compounds along the Maturation in Semi-arid Climate." M.Sc. thesis, Higher Institute of Agronomy, Technical University of Lisbon, Lisbon. (in Portuguese)

[14] Manfroi, V. 2004. Wine Tasting, 1st ed.. Porto Alegre: UFRGS Publisher, 127. (in Portuguese)

[15] Ribeiro, T. P., Lima, M. A. C., and Alves, R. E. 2012. "Maturation and Quality of Grapes for Juice in Tropical Conditions during the First Production Cycles." Brazilian Agricultural Research 47 (8): 1057-65. (in Portuguese)

[16] Dutra, M. C. P., Lima, M. S., Barros, A. P. A., Mascarenhas, R. J., and Lafisca, A. 2014. "Influence of Grape Variety on Analytical Characteristics and Sensorial Acceptance of Artisanal Juice." Brazilian Journal of Agroindustrial Products 16 (3): 265-72. (in Portuguese)

[17] Perez-Magarino, S., and González-San José, M. L. 2004. "Evolution of Flavanols, Anthocyanins and Their Derivatives during the Aging of Red Wines Elaborated from Grapes Harvested at Different Stages of Ripening." J. Agric. Food Chem. 52 (5): 1181-9.

[18] González-Neves, G., Barreiro, L., Gil, G., Franco, J., Ferrer, M., Moutounet, M., and Carbonneau, A. 2004. "Anthocyanic Composition of Tannat Grapes from the South Region of Uruguay." Analytica Chimica Acta 513 (1): 197-202.

[19] Giovaninni, E., and Manfroi, V. 2009. Viticulture and Enology: Elaboration of Great Wines in Brazilian Terroirs. Bento Gonçalves: IFRS. (in Portuguese) 